\title{
Addendum: Irrational behavior in C. elegans arises from asymmetric modulatory effects within single sensory neurons
}

\author{
Shachar Iwanir ${ }^{1,2}$, Rotem Ruach ${ }^{1,2}$, Eyal Itskovits (iD ${ }^{1}$, Christian O. Pritz ${ }^{1}$, Eduard Bokman ${ }^{1}$ \& Alon Zaslaver ${ }^{1}$
}

Addendum to: Nature Communications https://doi.org/10.1038/s41467-019-11163-3, published online 19 July 2019.

We would like to make our readers aware of the publication by Cohen et al., which reports irrational behaviour in C. elegans olfactory preference $^{1}$. These complementary studies establish C. elegans as a model system to explore the neural mechanisms of decision making.

Published online: 23 September 2019

\section{References}

1. Cohen, D. et al. Bounded rationality in C. elegans is explained by circuit-specific normalization in chemosensory pathways. Nat. Commun. 10, 1-12 (2019).

\begin{abstract}
(c) (i) Open Access This article is licensed under a Creative Commons Attribution 4.0 International License, which permits use, sharing, adaptation, distribution and reproduction in any medium or format, as long as you give appropriate credit to the original author(s) and the source, provide a link to the Creative Commons license, and indicate if changes were made. The images or other third party material in this article are included in the article's Creative Commons license, unless indicated otherwise in a credit line to the material. If material is not included in the article's Creative Commons license and your intended use is not permitted by statutory regulation or exceeds the permitted use, you will need to obtain permission directly from the copyright holder. To view a copy of this license, visit http://creativecommons.org/licenses/by/4.0/.
\end{abstract}

(C) The Author(s) 2019

\footnotetext{
${ }^{1}$ Department of Genetics, Silberman Institute of Life Science, Edmond J. Safra Campus, The Hebrew University of Jerusalem, Jerusalem 9190401, Israel. ${ }^{2}$ These authors contributed equally: Shachar Iwanir, Rotem Ruach. Correspondence and requests for materials should be addressed to A.Z. (email: alonzas@mail.huji.ac.il)
} 